\title{
Scientific and Methodological Support of the Individual Trajectory of Educators' Professional Development
}

\author{
Svitlana Makarenko \\ Department of Preschool Education, Philology and Mass Communication Faculty, Mariupol State University, Ukraine
}

Received November 29, 2019; Revised March 9, 2020; Accepted March 17, 2020

Copyright $(2020$ by authors, all rights reserved. Authors agree that this article remains permanently open access under the terms of the Creative Commons Attribution License 4.0 International License

\begin{abstract}
Changes in the content, forms, technologies of modern education, the fulfillment by teachers of new functions require additional assistance and support both in learning and continuous training, professional competence and creativity, and the professional development of educators in the workplace based on their individual needs and requirements. All the above provides scientific and methodological support for the individual trajectory of the educators' professional development. Based on the analysis of scientific literature, the article substantiates theoretically the essence of the concepts "individual educational trajectory", "individual trajectory of professional development". The conditions of the teacher's readiness to project the individual trajectory of professional development are determined. The current study reveals the content, structure, phased technology of scientific and methodological support of projecting and realization of the individual trajectory of the educator's professional development. Vector and targeted scientific and methodological support taking into account individual requests, needs, motivation of teachers, their professional capabilities and environmental requirements (administration, educational institution, society) are presented in the parameters of the target, technological and effective components of the support. The relevance of scientific and methodological support of the individual trajectory of the teachers' professional development is proved.
\end{abstract}

Keywords Individual Educational Trajectory, Individual Trajectory of the Educators' Professional Development, Individual Program of the Educators' Professional Development

Formal education will make you a living; self-education will make you a fortune Jim Rohn

\section{Introduction}

The main mission of modern education is to develop and prepare for an independent life of a successful and competitive person in the $21^{\text {st }}$ century. The guarantor of this mission is a teacher - theoretically trained, professionally competent, having academic freedom and developing professionally throughout life, independently and creatively acquiring information. From the knowledge translator, he/she turns into a partner, organizer of the child-centred education process with maximum approach to the opportunities, abilities, needs and guidance of a particular child. The modern teacher's functions are also updated: mentoring, coaching, facilitation, project training organization, start-ups mentoring, game pedagogy and moderation, tutoring of an individual educational personality trajectory and other. The role of administrative management and management in education is being strengthened. Accordingly, updating the requirements for the teachers' professional development causes the development of a new type of professionalism.

However,with the monitoring analysis of the teachers' professional activities, communication during methodical events and professional competitions, the polls show that changes in educational content, the growing number of various pedagogical technologies and innovations, the new functions performance cause some confusion and uncertainty. Either teachers or educational managers need additional training and professional competence development, counselling in the workplace. Equal assistance is needed in the free choice of organizers and programs, forms, types, pace of continuing professional development in formal, non-formal or informal education. The teachers' voluntary certification also raises no less questions.

In this case, the teacher professional development will be maximally effective in the light of his/her current individual needs and requirements and the free, independent projecting of his/ her own individual 
trajectory.

Therefore, operational targeted scientific and methodological support of the projecting and realization of individual trajectories of professional development, taking into account the individual needs, features and teachers' professional abilities, is relevant for the educators' professional development.

\section{Objectives}

The theoretical analysis of the issue indicates the thoroughness of the theoretical and methodological analysis by scientists of the concepts of "professionalization", "teacher's professional development" [1-14], on the different teachers' roles and models in educational policy [15-18], on the characterization of new social values - self-development, self-education, individual's self-projecting [19-25], on the development of the issue of the teacher's individual educational trajectory [26-36].

However, the definitions of the concepts "individual trajectory of professional development", "individual program of educator's professional development" so far remain controversial.

The purpose of our research is theoretical analysis of the concept "individual trajectory of educator's professional development" and revealing of the content, structure and phased technology of scientific and methodical support and its projecting and realization.

\section{Materials}

The era of the twenty-first century poses unprecedented challenges to the traditional ideal of professionalism. The former paradigm of the professional is outdated and the ideology of a "new" professionalism [6] and a new integrative concept of the formation of professional identity [7], including the teacher, are being developed. Evans [4] re-defined and examined the concept and substance of professionalism and offered new perspectives in the form of three distinct conceptions: demanded, prescribed and enacted professionalism. Exploring the existentialist status of "new" or "modified" professionalism and the relationship between professionality, professional culture and professionalism, she examined how professionalism may be interpreted and utilised for the development of education professionals [4].

In this context Scanlon [7] advocated the "ongoing" modality of developing a professional self throughout one's professional life and rightly pointed out that becoming a professional is a lifelong, extended process that constructs an individual's professional identity through formal education, workplace interactions and popular culture.
As for the concept of "professional development", Pukhovska [37] interpreted it as the development of a person in his/her professional role; Scheerens and Sleegers [38] - "as the body of systematic activities to prepare teachers for their job, including initial training, induction courses, in-service training, and continuous professional development within school settings"; Organisation for Economic Co-Operation and Development [OECD] [39] - "as activities that develop an individual's skills, knowledge, expertise and other characteristics as a teacher"; Khorzhevska [41] - as a product and result of a person's activities related to the development of personality, the assimilation of new experience, knowledge, skills, with the motivation and interests transformation of a particular person.

One cannot disagree with Evets [6] who argued, that at the same time there is a danger that excessive individualization and bureaucratization of professional activity will lead to undermining social cohesion and ability to work in a team, and is convinced that an integrative approach is the most appropriate, harmoniously combining the principles of "pure" and "organizational" professionalism.

Such an integrative approach ensures the continuous professional development of teachers on a self-projected basis, taking into account their own professional needs, requests from society and educational institution, individual trajectory.

The concept of "individual educational trajectory" is traditional, which Khutorskoy [42] has interpreted as a personal way of realizing one's personal potential in education. Some scientists $[32,36]$ have thought individual educational trajectory reflects the concrete results of not only education, but also the professional development of the individual. Polyakova [31] has considered the teacher's individual trajectory of education as an appropriate choice of education content, forms, methods, technologies, techniques based on an agreed teacher's individual objectives, needs, motives, interests and objectives, requirements of education organization or institution.

Sidorenko [35] has characterized the teacher's individual educational trajectory or individual itinerary as a specific innovation in the system of postgraduate pedagogical education, which provides a particularly organized differentiated akmeological educational space with a focus on search and mastering by the teacher of individual educational projects (programs) of pedagogical skill development, advanced training in variable and invariant credit (content) modules, blocks, etc., partially or completely independent, accelerated or prolonged training. At the same time, the scholar [35] defines the prospect outline of formation and teacher's further professional growth, directions, tools, forms of professional development, the prediction of probable risks in this way and means of overcoming them as the teacher's professional development trajectory. 
Emphasizing its spatiotemporal characteristics, a variety of other commentators have also made similar claims about individual educational trajectory as the trajectory of the individual educational movement, the «trace» (imprint, reflection), the line of motion which is formed by the fixation of the content of individual's attempts and experiences, educational achievements and characteristics of the individual educational space, which gives an opportunity in pedagogical forecasting and the project implementation (individual educational program) [32,33,36].

Polyakova [31] has drawn attention to the cyclicality of the process of choosing and building an individual education trajectory in connection with its focus on meeting educator's certain needs, motives, goals. Only if they are satisfied, new goals, needs, motives arise, and the cycle begins a new one rotation. This process ensures the education and self-development continuity of the teacher's personality. Polovenko \& Kirishko [40] have also emphasized this: the result of the individual educational trajectory realization is the continuous self-development of the personality of the teacher himself and his/her influence on the development of the personality of the student.

The above approach of scientists is consistent with Brody's \& Hadar's [29] position, who have explored trajectories of professional growth by teacher educators participating in a professional development community on teaching thinking and revealed a four stage model of personal professional trajectories: anticipation/curiosity (importance of thinking as a teaching goal, professional and personal growth, closing a professional gap), withdrawal (confirmation of professional competence, relabelling current practice, evidence for current expertise), awareness (motivation and goal setting, desire for using thinking routines, elaborated understanding of thinking routines) and change (change in practice, developing new expertise).

Mintzberg expressed good opinion regarding two-sided management education that emphasizes personal development in addition to cognitive training (as cited in [28]). Traditional management education focuses on the technical aspects, the "what" side of management. Paying attention to the "who" side of management requires a shift in mental models by excepting the relevance of subjective realities, personal values and social complexities (as cited in [28]). Senge introduced the term personal mastery to describe the discipline of continuous value-guided learning (as cited in [28]). The goal of personal mastery is to create a deeper level of self-awareness and authenticity, which in consequence leads to wiser choices.

It can be argued from this that individual educational trajectory projecting and directing requires an individual educational program (or project, plan, route, road map) of actions, movement. Scholars emphasize that such program should be differentiated, purposefully projected and implemented exclusively by a specific education subject on the basis of self-determination and self-realization. Some components of the program can be refined and adjusted in the course of the individual trajectory. We agree with Kovaleva's [32] definition, and we will interpret the individual program of educator's professional development as a program of educational and other activity of the subject of education, which is aimed at his/her personal, professional development, independently developed and implemented on the basis of his/her own educational, professional interests, needs and requests.

It should be noted that some scholars $[35,36]$ identify individual educational program with individual educational route; others $[33,34]$ emphasize the need for its detailing in individual educational route (or plan, road map), which is defined as a component of individual educational trajectory, planned in advance way of individual educational program realization with clear time and educational criteria, learning stage. Therefore, the set of individual educational routes under certain educational programs makes up the individual educational trajectory of the individual.

Thus, theoretical analysis has shown that scientists emphasize the logical connection between the concepts considered: first, an individual program (or project) is developed from a certain relevant aspect (direction, theme) of the teacher's professional development. The program can be detailed in an individual itinerary (plan, roadmap) and further implemented in an individual career path. Under these conditions, the individual trajectory of the teacher's continuing professional development reflects the specific results of the individual programs implementation on various aspects, and in general - the results of the teacher's professional and personal potential through the implementation of appropriate activities at all stages of professionalization [35].

Accordingly, we agree with the [33] definition, and we will understand the individual trajectory of educator's continuous professional development as an individual path in professional development, which is projected and implemented by the educator independently with the mentor's pedagogical support of his/her self-determination and self-realization; it is aimed at the realization of individual goals, life strategies, the formation of the foundations of personality's individual creative and professional development.

\section{Methods}

\subsection{Stages of Projecting Individual Trajectory of Professional Development}

In current conditions of continuous education, when the teacher's professional development is determined by the 
level of awareness of their own professional growth responsibility, teachers should learn to plan their personal professional development independently, taking into account both their own professional needs, opportunities, individual characteristics and society and educational institution requests; to project an individual trajectory of continuous professional development, focused on the achievement of the state of "acme", the pinnacle of professionalism.

We will reveal the content, structure, phased technology of scientific and methodological support of projecting and realization of the individual trajectory of educators' professional development in the parameters of the target, technological and effective components of support.

On the practice analysis basis, we agree with Khutorskoy's [42], Sharko's [14] conclusions, that the teacher's readiness to project and implement the individual trajectory of professional development is possible under the conditions:

- the presence of persistent and strong motives for self-education (motivational-orientation vector), criteria of evaluation of self-educational activity;

- a sufficient level of readiness for introduction of self-educational technologies (content-operational vector): to set goals for one's own professional development, determine its content, optimal forms and pace;

- the focus of self-education on the formation of innovative culture, personal development;

- reflexive awareness of the obtained results (ability to reflect) on the basis of self-control, objective evaluation of the development level of individual personal qualities and adjustment of their activity (evaluation-reflective vector).

Scientists and practitioners offer different forms of individual programs (or projects, routes, plans, roadmaps) building of professional development, and all of them are based on purpose, content, technological, organizational-pedagogical and effective structural components.

Phased projecting technology and realization of the individual trajectory of educator's professional development on the basis of an individual curriculum is being modelled on the basis proposed by Korneev \& Korneeva [34].

The $1^{\text {st }}$ Stage - diagnostics of the formation level of the educator's required professional competences.

The $2^{d}$ Stage - defining the purpose and priorities of professional development by the chosen aspect.

On the basis of diagnostics, the educator chooses an aspect (or direction, theme) of professional development that he/she needs to master and projects (in the form of theses, schemes, drawings or signs) his/her own vision (image, ideal) of this aspect.

Polyakova [31] has defined such directions (aspects) of the teachers' education and self-education individual trajectory:

1) professional competence development that will ensure the professional activity success: cognitive component (knowledge cognition and application ability), functional (ability to implement and replenish actions, fulfil functional responsibilities), behavioural (ability to identify behavioural components appropriate to the situation) and the personal component (ability to show personal and professionally significant qualities);

2) mastering the practice of self-management, which will allow to manage the most important resource - own time and own activity, using technologies of rational planning, self-organization, self-control, decision-making to ensure their own success;

3) improvement of all kinds of memory (short, long, semantic, figurative, etc.) of specialists as one of the successful professional activity conditions;

4) development of their own sphere of communication and interaction with other people, which will allow to effectively communicate, build and develop interpersonal (formal and non-formal) relationships, work, influence others and, if necessary, defend themselves against the psychological pressure of others, be a member of its organization team, to make efforts for formation of favourable social and psychological climate;

5) development of their intellectual and cultural potential, which will provide replenishment of their own resources (since the specificity of pedagogical activity is to impart knowledge, skills, emotions), to keep up with the times, to satisfy spiritual needs.

Having a clear vision of professional development direction or aspect, the teacher (together with the mentor) determines the goals and tasks of its realization in the individual trajectory of professional development.

The $3^{d}$ Stage - determination of the term of realization of the chosen aspect of professional development in accordance with the educator's goals and tasks, needs and interests.

The $4^{\text {th }}$ Stage - designing (programming) of individual professional development.

The educator (with the mentor's support) becomes the organizer of his/her own professional development: projects the purpose, professional development aspect, expected final results and forms of their presentation, develops a strategy and, if necessary - a working plan, chooses activity tools and methods, provides the process of monitoring and efficiency evaluation. This creates professional development individual program (or project, route, plan, roadmap) for a certain period.

The $5^{\text {th }}$ Stage - realization of professional development individual trajectory according to the developed program (project, route, plan, road map). 
At this stage, the developed individual program implementation and correction (if necessary) by the basic elements (purpose, plan, activity, reflection, comparison of the obtained products and self-evaluation) is carried out. If necessary - other specialists' involvement in the process of educator's professional development.

The $6^{\text {th }}$ Stage - presentation of professional development individual products and their collective discussion.

Presentation of educator's achievements according to the results of individual professional activity realization can be carried out in the presentation form of portfolio, project and certification works, etc.

The $7^{\text {th }}$ Stage - reflexive evaluation.

The formation level of educator's professionally significant qualities (including design skills) is monitored according to the quality evaluation criteria and indicators, individual activity products are analysed. The educator evaluates his/her own activity and the final product, the level of personal changes. Personal achievements are compared with basic research in this field, with the achievements of other practitioners. The correction and planning conditions of further collective and individual activity are created after self-evaluation and evaluation.

However, practical experience with educators proves, that the projecting and implementation of individual trajectory of professional development following individual programmes causes difficulties for the educators. Therefore, it is needed the support and assistance of mentor (coach, tutor, andragog) who will direct the activity and accompany every teacher, starting from the first stages of professional activity. And the school authority's task is to provide the conditions for teacher's realization of his/her individual trajectory of professional development with the support of specialists.

\subsection{Scientific and Methodological Support for the Educators' Professional Development}

In such circumstances, the role of scientific and methodological support is growing - a set of various forms of activity, procedures, events which provide assistance to specialists in overcoming difficulties throughout their professional activity; allow ensuring education continuity, involving of a wide range of specialists, who exchange ideas, views, experience, information [34]; pedagogical technology, which consists in the creation of a differentiated acmeological educational space, in which professional interaction of equal partners takes place on the principles of humanocentrism, humanism, facilitation, individualization, continuous development of pedagogical skills on the basis of a long life learning educational trajectory [35].

It is the support, providing training, methodological and psychological assistance, which provides not solving the problem for the teacher, not forcing the path of further professional development, but organizing and stimulating, directing his/her amateur activity to develop and implement professional development individual program, solving his/her own goals and problems according to the program.

Educational institutions leaders, specialists of local methodical offices (centres), heads of methodical associations of different educational institutions, methodists of educational institutions, supervisors, teacher-mentors have to carry out scientific and methodological support of projecting and realization of the educator's continuous professional development individual trajectory under the self-developed program.

The support form involves the movement of a mentor, a methodologist together, alongside a teacher who develops and implements his / her individual professional development program. navigates possible routes and, where necessary, provides support and assistance. Practice shows that the implementation of the individual program of professional development of the pedagogical worker is accompanied by the fixation of individual experience with successes and difficulties. It provides visibility and facilitates analytics and reflection, which means the success of the collaborative activities of the teacher and mentor on the individual program implementation.

Based on the foregoing, it is necessary to develop the content of scientific and methodological support of the teacher's professional development on an individual trajectory, which functions in the parameters of the target, technological and effective components of the human development process as a subject of professional activity. The most important thing here should be a personal approach that places increased demands on the teacher's intelligence, behaviour, professional qualities, self-determination, self-development and self-realization. After all, it is possible and necessary to teach an educator how to project an individual professional development trajectory, but he/ she can only form his/her own style, constantly enriching him-/herself as a person, expanding his/her own outlook, nurturing his/her feelings.

Modern requirements for scientific and methodological support make it possible to upgrade its functions (activity directions) to new and more effective ones. In particular, the following support functions are relevant in the context of projecting and realization of the teacher's professional development individual trajectory according to individual programs: tutoring, analytical, prognostic; coaching, developmental, educational, methodical, informational, consultative, consulting, supervision; generalizing, expert, corrective-reflective and other.

In the context of the target component of support of the teacher professional development on an individual trajectory motivation is important. Polovenko \& Kirishko [40] have determined the following motives that encourage self-education: changes in the education content; new training programs development; introduction of education non-standard forms; search for original 
teaching methods; designing a new pedagogical experience based on the science achievements and the chosen problem; improving knowledge of interest issues; competition; public opinion; personal qualities.

Accordingly, Bazil [12] has emphasized the importance of: firstly, achievements and shortcomings analysis by teachers of their own activities and forming an adequate view of their professional personality; secondly, the development of modern educator's reference image and his/her professional activity; thirdly, the inducement of educators to compare themselves with a reference image or exemplary models. For this reason, the scholar recommends the use of reflection and integrating ideas techniques within four planes:

- self-esteem of the teacher him-/herself, his/her activity and its results "here and now";

- retrospective analysis of the teacher him-/herself and his/her activity ("from the standpoint of the past");

- development by the teacher of his/her own image-ideal ("projection of the future");

- developing a sense of the teacher's perception of him-/herself "through the prism of the environment" (based on the awareness of the colleagues', parents', students', administration's assessments) [12].

This will not only serve as an effective motivator for the teaching staff professional growth, but will also help identify the activity strengths and weaknesses - the main aspects to develop individual programs of professional development.

Diagnostics and self-diagnosis should be carried out in order to choose the most relevant aspect (or direction, theme) of the teacher's professional development, who needs to master it, and the development of an appropriate individual program. The parameters of diagnostics can be psychological-pedagogical and teacher's professional training, pedagogical skills and abilities, activity efficiency, etc.

We have to note, that in this case not only teacher's internal needs, goals, motives, but also the external environment requirements (leadership, organization, society) should be taken into account. In particular, the chosen aspect of professional development should be consistent with the topic on which the educational institution is working, and the individual route (plan) of the individual program implementation the teacher compiles according to the institution annual plan.

Therefore, the scientific and methodological support is not to impose a mentor vision, but to help determine the most relevant, problematic aspect of professional activity (set new goals or change or adjust old ones) considering the methodical theme of the educational institution, the teacher's difficulties and interests.

Equally relevant in the context of scientific and methodological support is tutoring of the development of an individual program (or project, route, plan, road map) of professional development. The method of mental cards (or knowledge cards, mind maps, thinking cards, concept cards) - depicting the planning process with the help of diagrams, visualization technique and alternative recording of thinking can be effective here.

Also, the teacher's professional development program is assisted by an acmeogram, the components of which are the biography method, the acmeological file, the portfolio of the teacher-innovator. The acmeogram may contain analysis of types of pedagogical activity, its purpose, motives, means, structure, function, algorithms of actions and operations, providing for the educator's progressive development and professional self-improvement.

The individual program and therefore individual trajectory of professional development projected in this way will be oriented towards the achievement of the peak of professionalism by a particular educator, the main factors of which are creativity, self-study, self-improvement, self-planning and self-control.

In the future, it requires support and the necessary consultations for this information search for possible solutions to problem aspects and the construction of an action plan (or route, roadmap).

Accordingly, the technological component of scientific and methodological support of the professional development individual trajectory under the individual program is based on coaching, development, training, methodical, information, advisory, consulting functions and supervision.

Considering that the educator's professional development can be carried out of his/her own choice in different forms (types, directions) of continuous education, such directions are possible: the organized forms of the continuous education system (preparation, retraining, advanced training) in formal education; modelling of self-education and self-development content and means in non-formal and informal education.

Firstly, an integral part of the educators' continuing professional development is the system of professional development, which is radically updated and provides the individual with the right to freely choose an educational institution or other educational entity; educational program and types, forms, pace of education taking into account the results of self-assessment of competences and professional needs, content of their own teaching activities and/or responsibilities of educators. That is, professional development becomes not so much a duty as an important motivator for one's professional and career development.

Prominent here is the continuous scientific and methodological support: familiarization with the new advanced training system, identification of topics relevant for teachers; searching for the most appropriate advanced training forms and types, designing an action plan and the necessary consultations; as well as the scientific and methodological supervision of the learning process, 
preparation of creative works, publications, etc.

Moreover, practice shows that the implementation of the individual trajectory in organized forms of education is more limited than when implementing self-education. In view of this, professional growth, self-educational development of teacher in non-formal and informal education requires focused scientific and methodological support.

One of the functions of scientific and methodological support to assist specialists in the selection of content, forms and training methods in the continuing education system, taking into account the current opportunities of formal, non-formal, informal education and individual educational needs, is increasingly becoming consulting.

Secondly, the teachers' professional growth occurs in the educational environment of the educational institution in which they work. Bazil [12] notes such growth is within three main planes: on the basis of the reflection of professional activity performed, getting acquainted with the pedagogical experience of colleagues and gaining their own experience, affirmation of individual style of professional activity, self-actualization. Continuous scientific and methodological support is provided by the organization of effective forms of methodological work: theoretical and practical seminars, round tables, forums for discussion of relevant topics, meetings of creative communities (schools, workshops, laboratories), actions on self-assessment and self-presentation of pedagogical activity and experience (exhibitions, festivals, conferences, competitions, personal sites, blogs creation and support). Also, scientific and methodological support may take the form of curation of educator's project and research activity, preparation of publications, developments, general experience, seminars and conferences. There is also support of scientific and methodological work of educational institutions taking into account individual programs of educators' professional development.

This ensures a close integration of science and the educational process for the professional development of highly qualified, competitive educational staff, which is implemented as a process of mutual enhancement of the teacher's personal and professional qualities.

Thirdly, an important factor in the teaching staff professional development is self-education. Polovenko \& Kirishko [40] have defined such types of teachers' self-educational activity:

systematic acquaintance with novelties of methodical, pedagogical, subject literature and access to scientific and methodical sources (on paper, electronic media);

systematic review of educational television programs;

- surfing the Internet for information on methods of teaching subjects, pedagogy, psychology, educational technologies;

- solving Olympiad tasks, tests, independent external evaluation questions, crossword puzzles and other problems of increased complexity or non-standard form;

- listening to lectures, speeches;

- attending seminars, training, conferences, colleagues' lessons, discussions, meetings;

- experience exchange with colleagues;

- distance learning courses, training;

- organization of group and extracurricular activities in the subject;

- information technologies study;

- visiting exhibitions and thematic excursions;

- communication with colleagues in school, district, region and social networks;

- creative trips to experience sources;

- using the specialists' advice to improve their knowledge or skills;

- researching, etc.

The important functions of scientific and methodological support for the implementation of the individual trajectory in the programs of professional development of each teacher of the educational institution are counselling and supervision. In particular, supervision has become synonymous with methodical mentoring, which is called "therapy therapies". Sorochan [13] has defined supervision as professionally oriented assistance, taking into account the requirements of the working situation; cooperation, in the process of which the learners are given the opportunity to reflect their own difficulties, expand theoretical ideas, determine ways of further activity. Supervisor's activity is aimed at helping to combine theoretical knowledge with practical skills, pedagogical activity with training and encouraging the specialists to analyse their own activities, professional development, deeper mastery of professional skills at the level of modern requirements. The result of supervision is a new educator's experience, the development of his/her competencies, providing the solution of professional problems and understanding of professional development opportunities.

Equally important component of scientific and methodological support of the professional development of the pedagogical employee is effectiveness, assistance to the educator in reflection of professional development, evaluation of the effectiveness of implementation of the individual program and plan, awareness of the results obtained on the basis of objective self-assessment, and adjusting one's own activity. This component of support is especially relevant in the context of attestation and voluntary teachers' certification.

However, practice shows that self-assessment and self-reflection are the most difficult for teachers. Therefore, in the context of scientific and methodological support, a specialist at this professional development stage requires the generalization, expert, corrective and reflective functions of the mentor. In particular, the method of success evaluation and self-evaluation is better 
to choose the teacher him-/herself together with the mentor (if necessary) - it may be talking, discussing, completing diagnostic questionnaires, and so on.

Systematization and generalization of the specialist's professional skills will be provided by a portfolio (paper or electronic) of the professional development individual trajectory - as a means of demonstrating achievements, method of pedagogical diagnosis and intermediate and final assessment, self-assessment of the teacher's professionalism and the effectiveness of his/her educational activities.

The results of the teacher's work can be presented in the portfolio in the forms of reports, abstracts, speeches at methodical events and pedagogical councils; author's educational programs, training programs, methodological manuals, articles to the professional edition, scientific and methodological developments; projects, as well as the development of lessons, electronic manuals, technological maps, sets of electronic didactic materials, electronic media library; materials of own site, blog, etc. Methodical work forms through which author's developments can be presented are seminars-presentations of their own work experience, workshops, fairs, festivals, exhibitions (including virtual ones), etc.

In this case, the mentor's and methodologist's expert function in the analysis and evaluation of the specialist's activity will help in determining the state and prospects of his/her development by the selected criteria, will allow to explore the positive and negative trends in practice, to compare the results with the stated purpose and evaluate the individual professional development program.

The introduction of scientific and methodological support, in this way designed, provides a high level of teachers' professional growth on individual trajectories and programs. In particular, each teacher learns:

to see the best sides and difficulties of one's own professional activity;

to determine the immediate and future prospects for professional development;

- to conduct independently-creative search of professionally relevant information;

- independently plan professional development, taking into account one's own pedagogical abilities, qualities and potential opportunities, value attitudes, requests and needs;

- to project a self-organization and self-development system;

- to independently evaluate the quality of one's own educational activities and the results of professional development.

\section{Results and Conclusions}

Therefore, theoretical analysis of the scientific literature and practice confirmed the relevance of projecting and implementing the educators' professional development by individual trajectory and program (or project, route, plan, road map, etc.). This is due to their own needs in improving their professional competences and realizing the teacher's personal potential, as well as the needs of society.

We consider the educator's individual professional development trajectory as a specific innovation, leading technology of personality's formation and self-development - an individual path in professional development that pedagogical worker independently projects and implements with pedagogical support by mentor of his self-determination and self-realization, aiming at the realization of individual goals, life strategies, the formation of the foundations of person's individual creative and professional development.

Individual programs of realization of individual professional development trajectory help predict the teacher's development, taking into account his/her personal and professional requests and needs, experience, level of training, psychophysiological and cognitive characteristics and trace the trajectory of professional growth at each stage. At the same time, professional development on an individual trajectory allows the educator, while remaining within the general methodological theme of the educational institution, to realize the degree of his/her own readiness for its realization and to independently choose the content and strategy of professional development; to be self-reliant to think, independence, therefore, to maximize individualization of the process of professional growth on the basis of competent and personally-oriented approaches.

Leading technology of methodological assistance to the educator in the projection and implementation of the individual professional development trajectory, which most closely meets modern requirements, is the scientific and methodological support - a set of various forms of partnership interaction between the subjects of education, procedures, measures that provide assistance to specialists in overcoming difficulties throughout their professional activities. The vector and targeted orientation of scientific and methodological support determine the teachers' individual requests, needs, motivations, their professional capabilities, the requirements of the external environment (leadership, organization, society) in the parameters of the target, technological and productive components of the specialist's professional development process.

In particular, scientific and methodological support of the educator's individual professional development trajectory provides motivation for his/her development and self-development, determination of actual aspects (directions, themes) of professional development according to the results of diagnostics and self-diagnosis, training or assistance in projecting the individual educational trajectory and professional development 
programming, expedient choice of effective forms and types of advanced training based on knowledge of the current regulatory framework, supervision of educator's professional development, analysis of the professional activity quality, evaluation and self-evaluation of the implementation efficiency of individual professional development trajectory, adjustment of his/her further professional development.

The content of scientific and methodological support is implemented according to the newest functions: advisory, consulting, supervision, expert, prognostic, coaching, tutoring and others.

The prospect of further exploration in this area is considered as the development of a diagnostic model of evaluation and self-assessment of the level of professional development of educators and approbation of the model.

\section{REFERENCES}

[1] P. Halmos. Professionalisation and Social Change, University of Keile, Keile, 1973.

[2] P. J. DiMaggio, W. W. Powell. The Iron Cage Revisited: Institutional Isomorphism and Collective Rationality in Organization Fields, American Sociological Review, Vol.48, No.2, 147-160, 1983. Online available from DOI: $10.2307 / 2095101$.

[3] C. Day. Professional Development and Reflective Practice: Purposes, Processes and Partnerships, Pedagogy, Culture \& Society, Vol.7, No.2, 221-233, 1999. Online available from DOI: 10.1080/14681366.1999.11090864.

[4] L. Evans. Professionalism, Professionality and the Development of Education Professionals, British Journal of Educational Studies, Vol.56, No.1, 20-38, 2007. Online available

https://doi.org/10.1111/j.1467-8527.2007.00392.x

[5] D. Johnson, R. Maclean (eds.). Teaching: Professionalization, Development and Leadership, Springer, Dordrecht, 2009. Online available from https://doi.org/10.1007/978-1-4020-8186-6

[6] J. Evetts. A New Professionalism? Challenges and Opportunities, Current Sociology, Vol.59, No.4, 406-422, 2011. Online available from https://doi.org/10.1177\%2F0011392111402585

[7] L. Scanlon (ed.). "Becoming" a Professional: An Interdisciplinary Analysis of Professional Learning, Springer, Dordrecht, 2011. Online available from https://doi.org/10.1007/978-94-007-1378-9

[8] M. Taylor, A. Yates, L. H. Meyer, P. Kinsella. Teacher Professional Leadership in Support of Teacher Professional Development, Teaching and Teacher Education, Vol.27, No.1, 85-94, 2011. Online available from https://doi.org/10.1016/j.tate.2010.07.005

[9] C. Walter, J. Briggs. What Professional Development Makes the Most Difference to Teachers? Oxford University Press, Oxford, 2012.
[10] A. Gulamhussein. Teaching the Teachers. Effective Professional Development in an Era of High Stakes Accountability, Center for Public Education, Washington, D.C., 2013.

[11] B. A. Whitworth, J. L. Chiu. Professional Development and Teacher Change: The Missing Leadership Link, Journal of Science Teacher Education, Vol.26, No.2, 121-137, 2015. Online available from https://doi.org/10.1007/s10972-014-9411-2

[12] L. A. Basil. Profesiinyi Rozvytok Pedahoha v Umovakh Novoi Ukrainskoi Shkoly [Teacher's professional development in the conditions of New Ukrainian School], Zbirnyk Naukovykh Prats za Materialamy Vseukrainskoi Naukovo-Praktychnoi Konferentsii "Aktualni Problemy Literaturnoi Osvity" - Anall-Ukrainian workshop conference on "Actual problems of literary education", 2018. Online available from https:/lib.iitta.gov.ua/713003/1/\%D0\%A2\%D0\%B5\%D0 $\% \mathrm{~B} 7 \% \mathrm{D} 0 \% \mathrm{~B} 8 \% \mathrm{D} 0 \% \mathrm{~A} 3 \% \mathrm{D} 0 \% \mathrm{BC} \% \mathrm{D} 0 \% \mathrm{~B} 0 \% \mathrm{D} 0 \% \mathrm{BD}$ $\% \mathrm{D} 1 \% 8 \mathrm{C} \% \mathrm{D} 0 \% 91 \% \mathrm{D} 0 \% \mathrm{~B} 0 \% \mathrm{D} 0 \% \mathrm{~B} 7 \% \mathrm{D} 0 \% \mathrm{~B} 8 \% \mathrm{D} 0 \%$ $\mathrm{BB} \% \mathrm{D} 1 \% \overline{8} \mathrm{C} . p d f($ in Ukrainian).

[13] T. Sorochan. Profesionalizatsiia andrahoha: tsinnosti, znannia, navychky [Professionalization of the andragog: values, knowledge, skills], Pisliadyplomna osvita v Ukraini - Postgraduate Teacher Education, No.1, 53-57, 2018 (in Ukrainian).

[14] V. D. Sharko. Metodychna Pidhotovky Vchytelia Fizyky v Umovakh Neperervnoi Osvity [Methodical Training of the Teacher in the Continuous Education Conditions], KhDU, Kherson, 2006 (in Ukrainian).

[15] P. Croll, D. Abbott, P. Broadfoot, M. Osborn, A. Pollard. Teachers and Education Policy: Roles and Models, British Journal of Educational Studies, Vol.42, No.4, 333-347, 1994. Online available from https://doi.org/10.1080/00071005.1994.9974007

[16] W. Martino. Teachers as Role Models, In: L. J. Saha, A. G. Dworkin (eds.), International Handbook of Research on Teachers and Teaching. Springer International Handbooks of Education, vol.21, Springer, Boston, MA, 2009. Online available https://doi.org/10.1007/978-0-387-73317-3_47

[17] S. J. Ball, M. Maguire, A. Braun, K. Hoskins. Policy Actors: Doing Policy Work in Schools, Discourse: Studies in the Cultural Politics of Education, Vol.32, No.4, 625-639, 2011. Online available from https://doi.org/10.1080/01596306.2011.601565

[18] B. Hinnant-Crawford. Education Policy Influence Efficacy: Teacher Beliefs in Their Ability to Change Education Policy, International Journal of Teacher Leadership, Vol.7, No.2, 1-27, 2016. Online available from https://files.eric.ed.gov/fulltext/EJ1137496.pdf

[19] C. Argyris, D. A. Schön. Theory in Practice - Increasing Professional Effectiveness, Jossey-Bass Inc., San Francisco, 1974. Online available from https://doi.org/10.1002/bs.3830390308

[20] M. S. Knowles. Self-Directed Learning: A Guide for Learners and Teachers, Association Press, New York, 1975. Online available from https://doi.org/10.1177\%2F105960117700200220 
[21] D. A. Schön. The Reflective Practitioner: How Professionals Think in Action, Basic Books, New York, NY, 1983.

[22] D. A. Schön. Educating the Reflective Practitioner: Toward a New Design for Teaching and Learning in the Professions. Jossey-Bass, San Francisco, CA, 1987.

[23] J. Alsup. Teacher Identity Discourses: Negotiating Personal and Professional Spaces, Routledge, New York, 2005. Online available from https://doi.org/10.4324/9781410617286

[24] D. Mulcahy. Teacher Professional Becoming: A Practice-Based, Actor-Network Theory Perspective. In: L. Scanlon (ed.), "Becoming" a Professional: An Interdisciplinary Analysis of Professional Learning, Springer, Dordrecht, 2011. Online available from https://doi.org/10.1007/978-94-007-1378-9_11

[25] V. V. Oliynyk, M. O. Kyrychenko, O. M. Otych, T. M. Sorochan, O. I. Bondarchuk, N. H. Didenko, ... M. I. Skripnik. Problemy i perspektyvy rozvytku pisliadyplomnoi pedahohichnoi osvity $\mathrm{v}$ umovakh rozbudovy novoi ukrainskoi shkoly [Problems and Prospects of Postgraduate Pedagogical Education Development in Conditions of a New Ukrainian School Development], Naukove Zabezpechennia Rozvytku Osvity v Ukraini: Aktualni Problemy Teorii i Praktyky (do 25-richchia NAPN Ukrainy) - Scientific Support for the Development of Ukrainian Education: Actual Problems of Theory and Practice (Up to the 25th Anniversary of the National Academy of Sciences of Ukraine). S.V. Bartosh (ed.), Vydavnychyi dim «Sam», Kyiv, 2017 (in Ukrainian).

[26] C. Banfi. Some Thoughts on the Professional Development of Language Teachers, ELT News \& Views Supplement: Teacher Development, Vol.4, No.1, 14-27, 1997.

[27] A. Kennedy. Models of Continuing Professional Development: A Framework for Analysis, Journal of Inservice Education, Vol.31, No.2, 235-250, 2005. Online available

from https://www.tandfonline.com/doi/abs/10.1080/1367458050 0200277

[28] P. Berends, U. Glunk, J. Wüster. Personal Mastery in Management Education. A Case Description of a Personal Development Trajectory in Graduate Education, In: N. P. Barsky, M. Clements, J. Ravn \& K. Smith (eds.), Advances in Business Education, Vol.1, Springer, Dordrecht, 2008. Online available from https://doi.org/10.1007/978-1-4020-8747-9_7

[29] D. Brody, L. Hadar. "I Speak Prose and I Now Know It". Personal Development Trajectories Among Teacher Educators in a Professional Development Community, Teaching and Teacher Education, Vol.27, No.8, 1223-1234, 2011. Online available from https://doi.org/10.1016/j.tate.2011.07.002

[30] Ä. Leijen, K. Kullasepp. All Roads Lead to Rome: Developmental Trajectories of Student Teachers' Professional and Personal Identity Development, Journal of Constructivist Psychology, Vol.26, No.2, 104-114, 2013. Online available http://dx.doi.org/10.1080/10720537.2013.759023

[31] G. Polyakova. Napriamy Modeliuvannia Indyvidualnoi
Traiektorii Bezperervnoi Osvity Y Samoosvity Pedahohichnykh Pratsivnykiv [Directions of Individual Trajectory Modeling of Pedagogical Staff's Continuous Education and Self-Education], Teoriia ta Metodyka Upravlinnia Osvitoiu - Theory and Methodology of Educational Management, No.3, 1-11, 2010 (in Ukrainian).

[32] T. M. Kovaleva, E. I. Kobyshcha, S. Yu. Popova (Smolik), A. A. Terov, M. Yu. Cheredilina. Professiya "Tyutor" [Profession "The Tutor"], «SFK-ofis», Moskva-Tver, 2012 (in Russian).

[33] N. Yu. Shaposhnikova. Individualnaya Obrazovatelnaya Trayektoriya Studenta: Analiz Traktovok Ponyatiya [The Student's Individual Educational Trajectory: Analysis of Concepts], Pedagogicheskoye obrazovaniye v Rossii Pedagogical Education in Russia, No.5, 39-44, 2015. Online available from https://cyberleninka.ru/article/n/individualnaya-obrazovate lnaya-traektoriya-studenta-analiz-traktovok-ponyatiya/vie wer (in Russian).

[34] D. N. Korneev, N. Yu. Korneeva. Konstruirovaniye Individualnoy Obrazovatelnoy Trayektorii Obucheniya Studenta Sovremennogo Pedagogicheskogo Universiteta [Designing an Individual Educational Student Learning Trajectory at A Modern Pedagogical University], Pedagogicheskiye Nauki. Vestnik Chelyabinskogo Gosudarstvennogo Pedagogicheskogo Universiteta Pedagogical Sciences. Bulletin of Chelyabinsk State Pedagogical University, No.4, 51-56, 2017. Online available from https://cyberleninka.ru/article/n/konstruirovanie-individual noy-obrazovatelnoy-traektorii-obucheniya-studenta-sovre mennogo-pedagogicheskogo-universiteta/viewer (in Russian).

[35] V. V. Sidorenko. Naukovo-Metodychne Zabezpechennia Rozvytku Pedahohichnykh Navychok Spetsialistiv v Umovakh Vidkrytoi Osvity [Scientific and methodological support for the specialists' pedagogical skills development in the conditions of open education], In T. M. Sorochan (ed.), Navchalnyi Plan Profesiinoho Rozvytku Pedahohichnoho ta Naukovo-Pedahohichnoho Personalu ta Kerivnykiv Navchalnykh Zakladiv Haluzi Znan 01 Pedahohichna Osvita: Zbirnyk Robochykh Navchalnykh prohram - Curriculum of Professional Development of Pedagogical and Scientific-Pedagogical Staff and Educational Institutions Authorities of the Field of Knowledge 01 Pedagogical Education: Collection of Working Training Programs, TsIPPO, Kyiv, 2017 (in Ukrainian).

[36] O. M. Borovik. Do Pytannia pro Zmist Poniattia "Indyvidualna Osvitnia Traiektoriia Rozvytku Vchytelia" [On the Content of the Concept "Individual Educational Trajectory of Teacher's Development"], Zbirnyk Naukovykh Prats. Pedahohichni Nauky - Scientific Works Collection. Pedagogical Sciences, Vol.55, 234-238, 2010. Online available from http://ps.stateuniversity.ks.ua/file/issue_55/46.pdf

[37] L. Pukhovska. Teoretychni Zasady Profesiinoho Rozvytku Pedahohiv : Rukh do Kontseptualnoi Karty [Theoretical Foundations of the Teachers' Professional Development: The Movement to the Conceptual Map], Porivnialna Profesiina Pedahohika - Comparative Professional Pedagogy, No.1, 97-106, 2011. Online available from http://khnu.km.ua/root/res/2-7001-31.pdf (in Ukrainian). 
[38] J. Scheerens, P. J. C. Sleegers. Conceptualizing Teacher Professional Development as a Means to Enhancing Educational Effectiveness, In: J. Scheerens (ed.), Teachers' Professional Development, European Union, Luxembourg, 2010.

[39] Organisation for Economic Co-Operation and Development, Creating Effective Teaching and Learning Environments: First Results from TALIS, 2009. Online available from www.sourceoecd.org/education/9789264056053

[40] O. V. Polovenko, L. M. Kirishko. Bezperervna osvita pedahoha za indyvidualnoiu osvitnoiu traiektoriieiu [The Teacher's Continuing Education on the Individual Educational Trajectory], KZ «KOIPPO imeni Vasylia Sukhomlynskoho», Kropyvnytskyi, 2018 (in Ukrainian).

[41] I. M. Khorzhevska. Profesionalizm ta Profesiinyi Rozvytok Osobystosti [Professionalism and professional development of a person], Naukovi Pratsi. Derzhavne Upravlinnia - Scientific works. Public administration, Vol.214, No.202, 110-113, 2013. Online available from http://official.chdu.edu.ua/article/view/91202/86978 (in Ukrainian).

[42] A. V. Khutorskoy. Metodika lichnostno-oriyentirovannogo obucheniya. Kak obuchat vsekh po-raznomu? [Methods of personal-oriented training. How to teach everyone differently?], Izd-vo VLADOS-PRESS, Moscow, 2005 (in Russian). 